\title{
Therapeutic potentials of Crataegus azarolus var. eu- azarolus Maire leaves and its isolated compounds
}

\author{
Eman Abu-Gharbieh ${ }^{1,2^{*}}$ and Naglaa Gamil Shehab ${ }^{3}$
}

\begin{abstract}
Background: Hyperglycemia is a complicated condition accompanied with high incidence of infection and dyslipidemia. This study aimed to explore the phyto-constituents of Crataegus azarolus var. eu- azarolus Maire leaves, and to evaluate the therapeutic potentials particularly antimicrobial, antihyperglycemic and antihyperlipidemic of the extract and the isolated compound (3ß-O-acetyl ursolic acid).
\end{abstract}

Methods: Total phenolics and flavonoidal contents were measured by RP-HPLC analysis. Free radicals scavenging activity of different extraction solvents was tested in-vitro on DPPH free radicals. The antimicrobial activity of the ethanolic extract and its fractions as well as the isolated compounds were evaluated in-vitro on variable microorganisms. Animal models were used to evaluate the antihyperglycemic and antihyperlipidemic activities of the ethanolic extract along with the isolated compound ( $3 \beta-O$ acetyl ursolic acid).

Results: RP- HPLC analysis of the phenolics revealed high content of rutin, salicylic and ellagic acids. Six compounds belonging to triterpenes and phenolics were isolated from chloroform and $n$-butanol fractions namely: ursolic acid, 33-O-acetyl ursolic acid, ellagic acid, quercetin 3-O- $\beta$ methyl ether, rutin and apigenin7-O-rutinoside. Ethanolic extract showed the highest DPPH radical scavenger activity compared to other solvents. Ethanolic extract, hexane fraction, ursolic acid, $3 \beta-O$ acetyl ursolic acid and quercetin 3-O-methyl ether showed variable antimicrobial activity against E. coli, P. aeruginosa, S. aureus, and C. albicans. Administration of the ethanolic extract or $3 \beta-O$ acetyl ursolic acid orally to the mice reduced blood glucose significantly in a time- and dose-dependent manner. Ethanolic extract significantly reduced LDL-C, VLDL-C, TC and TG and increased HDL-C in rats. Ethanolic extract and 3ß-O acetyl ursolic acid reduced in-vitro activity of pancreatic lipase.

Conclusion: This study reveals that Crataegus azarolus var. eu- azarolus Maire has the efficiency to control hyperglycemia with its associated complications. This study is the first to evaluate antihyperglycemic and antihyperlipidemic potentials of $3 \beta-O$ acetyl ursolic acid.

Keywords: Crataegus azarolus var. eu- azarolus Maire, 3ß-O acetyl ursolic acid, Antimicrobial, Antihyperglycemic, Antihyperlipidemic

\footnotetext{
* Correspondence: eabugharbieh@sharjah.ac.ae

${ }^{1}$ Department of Basic Medical Sciences, College of Medicine, University of

Sharjah, Sharjah, United Arab Emirates

2Department of Pharmacology and Toxicology, Dubai Pharmacy College,

Dubai, United Arab Emirates

Full list of author information is available at the end of the article
} 


\section{Background}

Dyslipidemia and increased susceptibility to infections are two typical complications of diabetes mellitus. High glucose levels are highly associated with immune system impairment, particularly on neutrophils [1]. Hyperglycemia reduces the phagocytic activity and ability of neutrophils to form extracellular traps to kill bacteria [1]. On the other hand, hyperglycemia due to both insulin deficiency and insulin resistance significantly affect the lipid metabolic pathways [2]. Diabetic patients usually experience various cardiovascular complications of which dyslipidemia represents a main risk factor [2].

There has been a noticeable increase in the use of both traditional home remedies and herbal medicine instead of relying on conventional treatments [3]. This has caused traditional medicine to become of worldwide importance, with medicinal and economic effects [4].

Crataegus azarolus is indigenous to the Mediterranean Basin. Crataegus azarolus var. eu-azarolus Maire is a low, dense, spiny tree with a beautiful inflorescence up to $6 \mathrm{~m}$ tall and with orange fruits [5]. Phytochemical investigation of the plant was performed mainly on the flowers. Antioxidant activity and phenolic composition of the flowers extract were studied [6]. No available literatures concerning the pharmacological activity and the phytochemical constituents of the leaves were found.

In folk medicine, genus Crataegus (commonly called hawthorn in English and Zaarour in Arabic) is used for curing several ailments viz. central nervous, reproductive, cardiovascular and immune systems [7]. It also showed anti-inflammatory, cytotoxic, antioxidant, gastroprotective, antimicrobial, cardioprotective, antidiabetic and antiHIV activities [8-14].

Phytochemical investigations on genus Crataegus were mainly performed on the leaves, flowers and berries. The isolated compounds were: oligomeric procyanidins, bioflavonoid, polysaccharides, catecholamines, vitamin $\mathrm{C}$, saponins, tannins, cardiotonic amines, purine derivatives and ursolic acid [8-10, 15-18].

This study aimed to explore the phytochemical composition of Crataegus azarolus var. eu-azarolus Maire leaves' extract, assess its acute toxicity and investigate the free radical scavenging and therapeutic potentials particularly antimicrobial, antihyperglycemic and antihyperlipidemic activities.

\section{Methods}

\section{General}

Shimadzu 1700 spectrophotometer was used for UV absorption spectra. Melting points were determined on Electrothermal 9100 equipment. Mass spectra were measured on a Jeol Mass Spectrometer SSQ 7000, Digital DEC 300. NMR spectra were measured in DMSO or $\mathrm{CD}_{3} \mathrm{OD}$ or $\mathrm{CDCl}_{3} ;{ }^{1} \mathrm{H}-\mathrm{NMR}$ spectra were obtained at
$400 \mathrm{MHz}$ and ${ }^{13} \mathrm{C}-\mathrm{NMR}$ spectra at $100 \mathrm{MHz}$ on a JEOL GX-400 spectrometer with the chemical shifts ( $\delta \mathrm{ppm})$ expressed relative to TMS as internal standard. Precoated silica gel $60 \mathrm{~F}_{254}$ (Merck, Darmstadt, Germany) was used for the TLC analysis. Vacuum liquid chromatography (VLC) was performed on silica gel 60 GF (Merck, Darmstadt, Germany). Sephadex LH-20 (SigmaAldrich, St. Louis, Missouri, United States) and silica gel $100 \mathrm{C}_{18}$-Reversed Phase (Fluka, Switzerland) were also used. Analysis of phenolics was performed on Hewlett Packard HPLC (HP 1050HPLCDADw/Data System) equipped with a Hypersil-ODS (4.6 X $250 \mathrm{~mm}, 5 \mu \mathrm{m})$ column and a UV detector.

\section{Plant material}

Leaves of Crataegus azarolus var. eu-azarolus were collected during the fruiting stage in July 2012 from plants cultivated in Nablus, Palestine. The plant was identified by Professor Hassnaa Ahmed Hosny, Department of Botany, Faculty of Science, Cairo University, Egypt. A voucher specimen has been kept at the Herbarium of the Department of Pharmacognosy, Faculty of Pharmacy, Cairo University.

\section{Chemicals, drugs and biochemical kits}

All solvents were of analytical grade and obtained from Fisher Scientific. Sodium carboxymethylcellulose (CMC), 2,2-diphenyl-1-picrylhydrazyl (DPPH), gentamicin, fluconazole, alloxan, glibenclamide, cholesterol, lovastatin, orlistat, procaine pancreatic lipase type II, p-nitrophenyl butyrate (PNPB) and HMG-CoA reductase assay kit were purchased from Sigma-Aldrich (St. Louis, Missouri, United States). Folin-Ciocalteu reagent was obtained from Merck (Darmstadt, Germany). Lipid profile assessment kits including total cholesterol (TC), low density lipoprotein cholesterol (LDL-C), very low density lipoprotein cholesterol (VLDL-C), high density lipoprotein cholesterol (HDL-C) and triglycerides (TG) were purchased from Abcam-Cambridge, UK. Glucose estimation kit (kit Glu 1108, Test Strips, One Touch, Lifescan) was used to evaluate the blood glucose level.

\section{Plant leaves extraction \\ Selection of best extraction solvent for phenolic contents} Acetone, ethyl acetate, Methanol and 70\% ethanol were used individually for the extraction of the powdered leaves material (each $100 \mathrm{~g}$ ). Spectrophotometric methods were used to determine the phenolic and the flavonoid contents. The experiments were carried out in triplicate.

\section{Spectrophotometric determination of total phenolic and flavonoid contents}

Folin-Ciocalteu reagent was used to measure the phenolic content according to Oktay et al. [19]. Different 
concentrations from gallic acid $(10-50 \mu \mathrm{g} / \mathrm{mL})$ were prepared for the standard calibration curve. The absorbance was determined at $750 \mathrm{~nm}$. Results were calculated as mg gallic acid/g dry plant weight equivalent.

Aluminum chloride was used to assess the total flavonoid contents of the different extracts according to the procedure described by Dewanto et al. [20]. Serial dilutions of quercetin were used for preparation of the standard calibration curve. The absorbance was measured at $510 \mathrm{~nm}$. All the experiments were carried out in triplicate.

\section{RP- HPLC analysis}

Phenolic composition of $C$. azarolus var. eu- azarolus leaves was investigated in aliquots ( $1 \mathrm{~g}$, each) of the methanolic extract of the plant via RP-HPLC [21, 22] based on the method previously described by the authors [23]. For the phenolic acids composition, the UV detector was set at $280 \mathrm{~nm}$ while for flavonoids composition the UV detector was adjusted at $330 \mathrm{~nm}$. Quantification was based on peak area calculation and was done in triplicate.

\section{Large scale extraction and fractionation}

Air-dried powdered leaves of C. azarolus var. eu-azarolus $(2.5 \mathrm{Kg})$ were extracted at room temperature by maceration in ethanol $(70 \%, 10 \mathrm{~L} \times 3)$. The ethanolic extract was evaporated under reduced pressure at temperature $55{ }^{\circ} \mathrm{C}$ to provide $280 \mathrm{~g}$ residue. $200 \mathrm{~g}$ residue were successively fractionated with different solvents according to the polarity viz. $n$-hexane, chloroform and $n$-butanol saturated with water; while the remaining residual amount was saved for biological evaluation. Partitioning the ethanolic extract with different solvents yielded 20, 15 and $18 \mathrm{~g}$ of dried extractive respectively.

\section{Isolation of the constituents of the chloroform extract}

An accurately weighed amount of the chloroform extract $(13.0 \mathrm{~g})$ was applied on silica gel $60 \mathrm{GF}$ VLC column $(25 \mathrm{X} 5 \mathrm{~cm})$. Gradient elution was performed using hexane-chloroform, chloroform-ethyl acetate mixtures and ethyl acetate. Fractions (100 mL each) were gathered and monitored by TLC using different mobile phase (System A, chloroform-methanol 9.5:0.5 and System B, ethyl acetate: formic acid: acetic acid: water 10.0:1.0:1.0:0.5). Spots were located by visualization under $\mathrm{UV}_{365} \mathrm{~nm}$ before and after exposure to ammonia vapor and by spraying with $p$-anisaldehyde at $110{ }^{\circ} \mathrm{C}$. Similar fractions were pooled to yield 6 collective fractions (F1-F6). According to the weight of the fraction and the number of spots, fractions F3 and F5 were selected for further isolation.

F3: $(2.5$ g; 6 spots, $R f$ values $0.83,0.70,0.60,0.50,0.40$ and 0.34 , system A) upon rechromatography on a silica gel $100 \mathrm{C}_{18}$-RP column under reduced pressure $(20 \mathrm{X}$ $1.5 \mathrm{~cm}$ ), using methanol-water 9:1 as eluent, resulted in isolation of compounds 1 and 2.

F5: (1.2 g; 2 spots, $R f$ values 0.77 and 0.47 , System B) was exposed to three columns the first and second were on sephadex LH-20 (35 X $3 \mathrm{~cm}$; elution, methanolwater 9:1 then 8:2) the third one was a silica gel 100 $\mathrm{C}_{18}$ - $\mathrm{RP}$ under reduced pressure $(20 \mathrm{X} 1.5 \mathrm{~cm}$; elution, methanol-water 1:1) to afford compound 3.

\section{Isolation of the constituents of the n-butanol extract}

The $n$-butanol residue ( $15 \mathrm{~g})$ was fractionated by silica gel 60 GF VLC column $(30 \times 3.5 \mathrm{~cm})$. Mixtures from different solvents were used (chloroform-ethyl acetate, ethyl acetate and ethyl acetate-methanol). Fractions (200 $\mathrm{mL}$ each) were gathered and seen by TLC (System B and System C, chloroform: methanol: water 8.5:1.5: 0.1). Spots were located before and after exposure to ammonia vapor by visualization under $\mathrm{UV}_{365} \mathrm{~nm}$ and by spraying with $p$-anisaldehyde at $110{ }^{\circ} \mathrm{C}$. Similar fractions were pooled to yield 10 collective fractions (P1-P10). According to the weight of the fractions and the number of spots, fractions $\mathrm{P} 7$ and P8 were selected for further isolation.

P7: (1.5 g; 2 spots, $R f$ values 0.72 and 0.50 , System C) upon rechromatography on a silica gel $100 \mathrm{C}_{18}$-RP column under reduced pressure $(20 \times 1.5 \mathrm{~cm})$ using methanol: water 1:1 as eluent, resulted in isolation of compound 4.

P8: $(0.8$ g; 2 spots, $R f$ values 0.38 and 0.22 , System B) upon rechromatography on Sephadex LH-20 column $(35 \times 3 \mathrm{~cm})$ using methanol: water 8:2 as eluent then on silica gel $100 \mathrm{C}_{18}$ - $\mathrm{RP}$ column $(20 \mathrm{X} 1.5 \mathrm{~cm})$ using methanol: water 1:1 resulted in isolation of compounds 5 and 6.

\section{Antioxidant activity DPPH radical scavenging assay}

Ethanol (70\%), methanol, acetone, and ethyl acetate were used individually to extract the leaves. The free radicalscavenging activity was assessed by DPPH radical [24]. Different concentrations of leaves extracts concentrations $(3.9,7.8,15.6,31.3,62.5,125,250 \mu \mathrm{g} / \mathrm{ml})$ and ascorbic acid (AA), as standard compound, were analyzed in triplicate. The percentage inhibition of DPPH radical was calculated as follow:

$\%$ inhibition $=\left[\mathrm{A}_{0}-\left(\mathrm{A}_{1}-\mathrm{A}_{2}\right)\right] / \mathrm{A}_{0} \times 100 \%$.

$\mathrm{A}_{0}$ : control absorbance, $\mathrm{A}_{1}$ : absorbance of the sample, $\mathrm{A}_{2}$ : absorbance of the sample in ethanol without DPPH.

\section{Biological study Microorganisms}

Three bacterial strains and one fungus, were kindly provided by Rashid hospital (Dubai-UAE) and were used 
for the antimicrobial screening. This included one representative of the Gram-positive group (Staphylococcus aureus RMTCC 3161), two representatives of the Gramnegative group (Escherichia coli RMTCC 2682 and Pseudomonas aeruginosa RMTCC 1687) and one fungus (Candida albicans RMTCC 5122). Microorganisms were grown on appropriate media: nutrient agar for $S$. aureus and $P$. aeruginosa, MacConkey agar for E. coli and Sabouraud dextrose agar for C. albicans.

\section{Antimicrobial activity}

The ethanolic extract, and its fractions, $n$-hexane, chloroform and $n$-butanol as well as the isolated compounds of C. azarolus at doses of $375 \mu \mathrm{g} / \mathrm{mL}$ for each extract, and $140 \mu \mathrm{g} / \mathrm{mL}$ for the isolated compounds were subjected to in-vitro qualitative screening, for evaluation of their antimicrobial potentialities. The agar diffusion technique was used [25]. Solubilization of the samples was assisted by sterile DMSO. The effects were compared with gentamicin $(30 \mu \mathrm{g} / \mathrm{mL})$ and antifungal, fluconazole $(30 \mu \mathrm{g} / \mathrm{mL})$. Diameters of zones of inhibition (in $\mathrm{mm}$ ) were taken as a measure for the growth inhibitory activity against the selected strains.

\section{Experimental animals}

Male albino mice (30 $\pm 5 \mathrm{~g})$ were used for acute toxicity and antihyperglycemic studies. Antihyperlipidemic experiments were performed on Sprague Dawley rats weighing $210 \pm 5 \mathrm{~g}$. All animals were kept under standard conditions, fed with regular diet and water supplied ad libitum. Mice were accommodated for 1 week prior to the experiments. All animal investigations were accepted from the Ethical Research Committee of the Dubai Pharmacy College, Dubai UAE and done according to the ethical standards of laboratory animals [26].

\section{Acute oral toxicity study}

$\mathrm{LD}_{50}$ was determined by probit test [27]. Mice were divided into five groups (10 each) and they received various oral doses of the ethanolic extract $(250,500$, 1000,2500 and $5000 \mathrm{mg} / \mathrm{kg}$ ). Later, they were observed over $72 \mathrm{~h}$ for any signs of morbidity or abnormal behavior and their death was recorded [27].

\section{Evaluation of antihyperglycemic activity Induction of diabetes in mice}

One night before the induction of hyperglycemia, the animals were kept fasted but given water ad libitum. The next morning, animals were injected $150 \mathrm{mg} / \mathrm{kg}$ alloxan monohydrate solution in acetate buffer $(0.15 \mathrm{M}, \mathrm{pH} 4.5)$ intraperitoneally. The animals were observed over a week and their blood glucose values were measured. Mice with blood glucose levels between 180 and
$360 \mathrm{mg} / \mathrm{dL}$ were assigned diabetic and were used later for further studies [28].

\section{Oral glucose tolerance test}

Animals were divided into four groups ( $n=6$ each). The mice were fasted for $18 \mathrm{~h}$ and provided water ad libitum. Each animal serves as its own control, Group I received only glucose at dose of $2 \mathrm{~g} / \mathrm{kg}$. Groups II and III received 250 and $500 \mathrm{mg} / \mathrm{kg}$ of the ethanolic leaves extract respectively, while group IV received the isolated compound in a dose of $50 \mathrm{mg} / \mathrm{kg}$. All the tested samples were given orally $90 \mathrm{~min}$ before the glucose dose $(2 \mathrm{~g} / \mathrm{kg}$, p.o.). Levels of blood glucose were calculated before and subsequently at 30, 60, 120 and 240 min after the administration of glucose dose. Blood glucose was measured by glucose estimation kit.

\section{Experimental procedure}

The diabetic animals were divided into five groups ( $n=6$ each). Group I kept as control, group II received $5 \mathrm{mg} / \mathrm{kg}$ glibenclamide as positive control, groups III and IV received the extract at doses of 250 and $500 \mathrm{mg} / \mathrm{kg}$ respectively, and group $\mathrm{V}$ received the isolated compound (2) at dose of $50 \mathrm{mg} / \mathrm{kg}$. Levels of the blood glucose were measured pre and post (120 and $240 \mathrm{~min}$ ) the treatment.

\section{Evaluation of antihyperlipidemic activity Induction of hyperlipidemia in rats}

The rats were fed daily by means of gavage tube with cholesterol at $25 \mathrm{mg} / \mathrm{kg}$ suspended in coconut oil given at $10 \mathrm{~mL} / \mathrm{kg}$ daily for 30 days [29].

\section{Experimental procedure}

The animals were grouped into five treatment categories ( $n=6$, each), as following: Group I, kept as control group received daily $1 \% w / v$ sodium CMC suspension. Animals in groups II-V were hyperlipidemic and received daily cholesterol (25 mg/kg/day) in oil at 10:00 am. Group II represented the hyperlipidemic group, group III served as positive control and received lovastatin $(10 \mathrm{mg} / \mathrm{kg} /$ day $)$ at 3:00 pm. Similarly groups IV and V were given the ethanolic leaves extract at doses of 250 and 500 respectively at $3: 00 \mathrm{pm}$. For a period of 30 days, the original and the final body weights and food intake of rats were monitored.

After this period, the fasted rats were sacrificed. Under ether anesthesia, samples of the blood were gathered by cardiac puncture. Lipid profile test was done including TC, HL-C, LDL-C, VLDL-C and TG.

Additionally, cardiac risk indicators were calculated by the "Atherogenic Index" TC: HDL-C ratio and LDL-C: HDL-C ratio. 
In-vitro evaluation of the effect of the ethanolic extract and its isolated compound (2) on pancreatic lipase and HMGCoA reductase activities

In-vitro lipase inhibitory effect of the ethanolic leaves extract and the isolated compound (2) was assessed according to the method previously described [30]. The final concentrations of the tested samples of the plant extract and isolated compound were ranged from 50 to $500 \mu \mathrm{g} / \mathrm{mL}$ and $20-200 \mu \mathrm{g} / \mathrm{mL}$ respectively.

The following formula was used to calculate the percentage inhibitory activity (I):

$$
\mathrm{I}=100-[(\mathrm{B}-\mathrm{b}) /(\mathrm{A}-\mathrm{a}) \times 100]
$$

Where A: activity without inhibitor; a: negative control in absence of inhibitor; B: activity in presence of inhibitor; and b: negative control in presence of inhibitor.

Orlistat and DMSO were used as positive and negative control respectively and their activities were also tested.

For the in-vitro evaluation of HMG-CoA inhibitory activity, similar concentrations range of the plant extract and isolated compound were used. Pravastatin was used as standard drug with concentrations ranged from $0.1-$ $2.5 \mu \mathrm{g} / \mathrm{mL}$ according to the method previously described [31]. HMG-CoA reductase inhibitory activity was calculated by using the following formula:

Inhibitory activity $(\mathrm{I} \%)=(\Delta$ Absorbance control- $\Delta$ Absorbance test/ $\Delta$ Absorbance control) $\times 100$.

\section{Statistical analysis}

The results were expressed as mean + S.E.M (Standard Error Mean). Data was analyzed by GraphPad Software version 6.00 (San Diego, CA). One-Way ANOVA followed by Bonferroni's multiple comparison tests against the control was performed. For repeated measures in glucose tolerance test, two-way ANOVA assessed the interactive and independent effects of treatment and time. $P$ values $<0.05$ were considered significant. $\mathrm{IC}_{50}$ values for the $\mathrm{DPPH}$ radical scavenging, pancreatic lipase Inhibition and HMGCoA inhibition assays were determined from the dose-response curves using a linear regression analysis. For invitro evaluation of pancreatic lipase and HMG-CoA inhibition activities, inhibition of less than $40 \%$ was considered irrelevant and was selected as a cutoff point.

\section{Results}

Spectrophotometric determination of total phenolic and flavonoid contents

Different solvents were used for leaves extraction for the flavonoid and the phenolic contents to select the safest and the most effective extracting solvent as shown in Table 1. Spectrophotometric analysis revealed that ethanol was the best solvent to extract both flavonoids and phenolic acids.
Table 1 Flavonoid and phenolic acids contents of C.azarolus var. eu- azarolus leaves extracts

\begin{tabular}{llll}
\hline Solvent & $\begin{array}{l}\text { Extraction } \\
\text { yield }(\%)^{\mathrm{a}}\end{array}$ & $\begin{array}{l}\text { Total flavonoid content } \\
(\mathrm{mg} \text { quercetin/g) }\end{array}$ & $\begin{array}{l}\text { Total phenolic } \\
\text { content }(\mathrm{mg} \mathrm{GAE} / \mathrm{g})\end{array}$ \\
\hline Ethanol & $20.0 \pm 1.2$ & $1.5 \pm 0.2$ & $1.5 \pm 0.6$ \\
Methanol & $12.3 \pm 1.7$ & $1.1 \pm 0.3$ & $1.3 \pm 0.7$ \\
Ethyl acetate & $9.7 \pm 0.8$ & $0.9 \pm 0.0$ & $0.6 \pm 0.0$ \\
Acetone & $2.4 \pm 0.3$ & $0.7 \pm 0.1$ & $0.1 \pm 0.0$ \\
\hline
\end{tabular}

${ }^{a}$ Expressed as $100 \times$ ( $g$ dry extract/g dry leaves)

\section{RP- HPLC analysis}

RP-HPLC analyses of the methanolic leaves extract of $C$. azarolus var. eu-azarolus Maire revealed that 11 components were identified at $\lambda=280 \mathrm{~nm}$ (corresponding to $37.73 \%$ of the total composition, Table 2) among which 8 were phenolic acids (30.77\%) with prevalence of salicylic acid (11.91\%) and ellagic acid (9.78\%) and one flavonoid (catechin) besides the diphenol, catechol; meanwhile, at $\lambda=330 \mathrm{~nm}, 7$ components were known (Table 3); six of which were flavonoidal compounds with the major rutin (6.50\%). (RP-HPLC chromatograms are available as Additional file 1).

\section{Isolation of the constituents of the chloroform and n-butanol extracts \\ Isolated compounds}

Compound 1 (ursolic acid): Molecular formula, C30 H48 O3; white powder; $20 \mathrm{mg}$; soluble in chloroform; Rf: 0.70 (System A); gave positive test for sterols and/or triterpenes; m.p., $286{ }^{\circ} \mathrm{C}$; EI-MS m/z (\% rel. Intensity) 456; ${ }^{1} \mathrm{HNMR}$ (400 MHz, CDCl3): $\delta \mathrm{H} \mathrm{0.79,} \mathrm{0.98,} \mathrm{0.97,} 1.0$ and $1.2\left(15 \mathrm{H}, 5 \mathrm{~s}\right.$, all $\left.\mathrm{CH}_{3}\right), 0.93,(3 \mathrm{H}, \mathrm{d}, J=6.4 \mathrm{~Hz}, \mathrm{H}-$ 30), $0.94(3 \mathrm{H}, \mathrm{d}, J=6 \mathrm{~Hz} . \mathrm{H}-29), 1.62(2 \mathrm{H}, \mathrm{m}, \mathrm{H}-21)$, 1.38 (2H, m, H-16), 2.10 (d, 1H, J = 15 Hz, H-18), 3.32 $(1 \mathrm{H}, \mathrm{dd}, J=10.8,4.4 \mathrm{~Hz}, \mathrm{H}-3), 5.30(1 \mathrm{H}, \mathrm{t} ; J=3.6 \mathrm{~Hz}$, H-12).

Table 2 RP-HPLC analysis of phenolics components of $C$. azarolus var. eu-azarolus leaves extract at $\lambda=280 \mathrm{~nm}$

\begin{tabular}{lll}
\hline Retention time & Identified component & Relative area \% \\
\hline 6.81 & Pyrogallol & 0.17 \\
6.92 & Gallic acid & 0.24 \\
8.235 & Protocatechuic acid & 3.95 \\
8.444 & Catechin & 4.82 \\
8.593 & Chlorogenic acid & 2.97 \\
8.950 & Catechol & 1.90 \\
10.040 & Caffeic acid & 0.75 \\
11.620 & Ferulic acid & 0.75 \\
12.466 & Salicylic acid & 11.91 \\
12.943 & Ellagic acid & 9.78 \\
14.980 & Cinnamic acid & 0.47 \\
Total identified constituents & 37.73 \\
\hline
\end{tabular}


Table 3 RP-HPLC analysis of phenolics components of $C$. azarolus var. eu-azarolus leaves extract at $\lambda=330 \mathrm{~nm}$

\begin{tabular}{lll}
\hline Retention time & Identified component & Relative area \% \\
\hline 3.83 & Quercetin & 0.01 \\
11.78 & Rosmarinic acid & 0.89 \\
12.44 & Rutin & 6.50 \\
14.576 & Narenginin & 0.43 \\
14.952 & Hispertin & 0.80 \\
16.167 & Apigenin & 0.16 \\
18.657 & Chrysin & 0.82 \\
Total identified constituents & & 9.61 \\
\hline
\end{tabular}

Compound 2 (3 $\beta-\mathrm{O}$ acetyl ursolic acid): Molecular formula, $\mathrm{C}_{32} \mathrm{H}_{50} \mathrm{O}_{4}$; white powder; $300 \mathrm{mg}$; soluble in chloroform; $\mathrm{R}_{f}: 0.60$ (System A); gave positive test for sterols and/or triterpenes; m. p., $268-270{ }^{\circ} \mathrm{C}$; EI-MS m/z (\% rel. Intensity) $498 ;{ }^{1} \mathrm{HNMR}$ (400 MHz, DMSO): $\delta_{\mathrm{H}}$ $0.76,0.85,0.87,1.00,1.1\left(15 \mathrm{H}, 5 \mathrm{~s}, \mathrm{CH}_{3}\right), 0.87(3 \mathrm{H}, \mathrm{d}$, $J=6.4 \mathrm{~Hz} \mathrm{H}-30), 0.91(3 \mathrm{H}, \mathrm{d}, J=6 \mathrm{~Hz} . \mathrm{H}-29), 1.21$ $(2 \mathrm{H}, \mathrm{m}, \mathrm{H}-21), 1.26(2 \mathrm{H}, \mathrm{m}, \mathrm{H}-16), 2.15(1 \mathrm{H}, \mathrm{d}$, $J=12 \mathrm{~Hz}, \mathrm{H}-18), 2.41(3 \mathrm{H}, \mathrm{s}, \mathrm{OAc}), 4.43(1 \mathrm{H}, \mathrm{dd}$, $J=10.8,4.4 \mathrm{~Hz}, \mathrm{H}-3), 5.1(1 \mathrm{H}, \mathrm{t}, J=3.6 \mathrm{~Hz}, \mathrm{H}-12)$.

${ }^{13} \mathrm{C}$ NMR data for compounds 1 and 2 were recorded in Table 4.

Compound 3 (ellagic acid): Molecular formula, $\mathrm{C}_{14} \mathrm{H}_{6} \mathrm{O}_{8}$; yellow crystalline; $15 \mathrm{mg}$; soluble in methanol; $\mathrm{R}_{f}: 0.47$ (System B); gave positive test for $\mathrm{FeCl}_{3}$; m.p. $370{ }^{\circ} \mathrm{C}$, EI-MS m/z (\% rel. Intensity) 302 ; colour in visible light, yellowish brown; Under UV light and under UV/ammonia, brown, UV $\lambda_{\max } \mathrm{nm}: \mathrm{CH}_{3} \mathrm{OH}, 253,354 ;{ }^{1} \mathrm{H}$ NMR (400 MHz, CD $3 \mathrm{OD}): \delta_{\mathrm{H}} 7.49\left(1 \mathrm{H}, \mathrm{s}, \mathrm{H}-5^{\prime}\right)$ and $7.67(1 \mathrm{H}, \mathrm{s}, \mathrm{H}-5)$.

Compound 4 (quercetin $3-\mathrm{O} \quad-\beta$ methyl ether): Molecular formula, $\mathrm{C}_{16} \mathrm{H}_{12} \mathrm{O}_{7}$, yellow powder, $35 \mathrm{mg}$; soluble in methanol; $\mathrm{R}_{f}$. 0.50 (System C); yellowish brown in visible light; brown under $\mathrm{UV}_{365 \mathrm{~nm}}$ light and yellow under $\mathrm{UV}_{365 \mathrm{~nm}} / \mathrm{NH}_{3}$, UV $\lambda_{\max } \mathrm{nm}: \mathrm{CH}_{3} \mathrm{OH}, 256$, 294sh, 358; $\mathrm{CH}_{3} \mathrm{ONa}, 270,331,407 ; \mathrm{AlCl}_{3}, 274,300$ sh, 336, 440; $\mathrm{AlCl}_{3} / \mathrm{HCl}, 264,300$ sh, 360, 402; NaOAc, 273, 323, 380; $\mathrm{NaOAc} / \mathrm{H}_{3} \mathrm{BO}_{3}, 262$, 297sh, 380; ${ }^{1} \mathrm{HNMR}$ (400 MHz. DMSO): $\delta_{\mathrm{H}} 3.84\left(3 \mathrm{H}, \mathrm{s}, \mathrm{OCH}_{3}\right), 6.21(1 \mathrm{H}, \mathrm{d}$, $J=2 \mathrm{~Hz}, \mathrm{H}-6), 6.49(1 \mathrm{H}, \mathrm{d}, J=2 \mathrm{~Hz}, \mathrm{H}-8), 6.84(1 \mathrm{H}, \mathrm{d}$, $\left.J=8.4 \mathrm{~Hz}, \mathrm{H}-5^{\prime}\right), 7.40\left(1 \mathrm{H}, \mathrm{dd}, J=2.0,8.0 \mathrm{~Hz}, \mathrm{H}-6^{\prime}\right)$, $7.70\left(1 \mathrm{H}, \mathrm{d}, J=2 \mathrm{~Hz}, \mathrm{H}-2^{\prime}\right)$.

Compound 5 (rutin): Molecular formula $\mathrm{C}_{27} \mathrm{H}_{30} \mathrm{O}_{16}$; yellow powder; $20 \mathrm{mg}$; soluble in methanol; $\mathrm{R}_{f}$ : 0.38 (system B); m.p. $245{ }^{\circ} \mathrm{C}$; brown in visible light, dull brown under $\mathrm{UV}_{365 \mathrm{~nm}}$, and yellow under $\mathrm{UV}_{365 \mathrm{~nm}} / \mathrm{NH}_{3}$; UV $\lambda_{\max }$ nm: $\mathrm{CH}_{3} \mathrm{OH}, 260,266$ sh, 300 sh, 356; $\mathrm{CH}_{3} \mathrm{ONa}, 278,327,411 ; \mathrm{AlCl}_{3}, 270,301$ sh, 430; $\mathrm{AlCl}_{3} /$ $\mathrm{HCl}, 267,298,360$ sh, 400; $\mathrm{NaOCOCH}_{3}, 269,325,390$; $\mathrm{NaOAc} / \mathrm{H}_{3} \mathrm{BO}_{3}, 261,300,385 ;{ }^{1} \mathrm{HNMR},(400 \mathrm{MHz}$,
Table $4{ }^{13} \mathrm{C}$ NMR (100 MHz) data of compounds 1 and 2

\begin{tabular}{|c|c|c|}
\hline NO.C & $\begin{array}{l}\text { Compound } 1 \\
\left(\mathrm{CDCl}_{3}\right)\end{array}$ & $\begin{array}{l}\text { Compound } 2 \\
\text { (DMSO) }\end{array}$ \\
\hline 1 & 38.6 & 39.0 \\
\hline 2 & 28.1 & 28.1 \\
\hline 3 & 78.5 & 79.8 \\
\hline 4 & 38.8 & 38.5 \\
\hline 5 & 55.2 & 55.3 \\
\hline 6 & 18.3 & 18.4 \\
\hline 7 & 32.7 & 32.7 \\
\hline 8 & 39.3 & 39.5 \\
\hline 9 & 47.6 & 47.4 \\
\hline 10 & 37.1 & 37.0 \\
\hline 11 & 23.8 & 23.7 \\
\hline 12 & 125.6 & 125.8 \\
\hline 13 & 140.6 & 138.9 \\
\hline 14 & 41.7 & 42.1 \\
\hline 15 & 27.7 & 28.0 \\
\hline 16 & 24.6 & 24.4 \\
\hline 17 & 47.5 & 47.5 \\
\hline 18 & 53.6 & 53.0 \\
\hline 19 & 39.4 & 39.4 \\
\hline 20 & 39.1 & 39.2 \\
\hline 21 & 31.8 & 30.7 \\
\hline 22 & 37.0 & 37.4 \\
\hline 23 & 28.5 & 29.0 \\
\hline 24 & 16.0 & 15.6 \\
\hline 25 & 15.6 & 16.5 \\
\hline 26 & 17.1 & 17.5 \\
\hline 27 & 23.9 & 23.3 \\
\hline 28 & 180.0 & 182.0 \\
\hline 29 & 17.1 & 17.5 \\
\hline 30 & 21.2 & 21.5 \\
\hline OAC & & 22.3 \\
\hline $\mathrm{CH}_{3} \mathrm{COO}$ & & 171.0 \\
\hline
\end{tabular}

$\left.\mathrm{CD}_{3} \mathrm{OD}\right): \delta_{\mathrm{H}} 6.11(1 \mathrm{H}, \mathrm{d}, J=2 \mathrm{~Hz} \mathrm{H}-6), 6.31(1 \mathrm{H}, \mathrm{d}$, $J=2 \mathrm{~Hz}, \mathrm{H}-8), 6.78\left(1 \mathrm{H}, \mathrm{d}, J=8.4 \mathrm{~Hz}, \mathrm{H}-5^{\prime}\right), 7.57(2 \mathrm{H}$, d, $\left.J=8.4 \mathrm{~Hz}, \mathrm{H}-2^{\prime}, \mathrm{H}-6^{\prime}\right)$; $3.33-3.67(12 \mathrm{H}, \mathrm{m}$ of sugar moieties), $4.41(1 \mathrm{H}, \mathrm{d}, J=1.5 \mathrm{~Hz}, \mathrm{Rham}), 1.07(3 \mathrm{H}, \mathrm{d}$, $J=6 \mathrm{~Hz}, \mathrm{CH}-\mathrm{Rham}), 5.2(1 \mathrm{H}, \mathrm{d}, J=7.8 \mathrm{~Hz}, \mathrm{H}-1 \mathrm{Glu})$.

Compound 6 (apigenin 7-O- $\beta$-D-glucopyranosyl $(6 \rightarrow 1)-\alpha$-L-rhamnopyranosyl-): yellow powder; $15 \mathrm{mg}$; soluble in methanol; $\mathrm{R}_{f}: 0.22$ (system $\mathrm{B}$ ); brown in visible light, dull brown under $\mathrm{UV}_{365 \mathrm{~nm}}$, and yellowish green under $\mathrm{UV}_{365 \mathrm{~nm}} / \mathrm{NH} 3$; UV $\lambda_{\max } \mathrm{nm}: \mathrm{CH}_{3} \mathrm{OH}, 267,335$; $\mathrm{CH}_{3} \mathrm{ONa}, 247$ sh, 267, 300 sh, 385; $\mathrm{AlCl}_{3}, 272,300,350$, 381; $\mathrm{AlCl}_{3} / \mathrm{HCl}, 270,300,347,380 ; \mathrm{NaOCOCH}_{3}, 254 \mathrm{sh}$, 
265; 355, 385; $\mathrm{NaOAc} / \mathrm{H}_{3} \mathrm{BO}_{3}, 272,373 ;{ }^{1} \mathrm{H}-\mathrm{NMR}$, $\left(400 \mathrm{MHz}, \mathrm{CD}_{3} \mathrm{OD}\right): \delta_{\mathrm{H}} 7.91\left(2 \mathrm{H}, \mathrm{d}, J=9.1 \mathrm{~Hz}, \mathrm{H}-2^{\prime}\right.$, H-6'), $7.03\left(2 \mathrm{H}, \mathrm{d}, J=8.8 \mathrm{~Hz}, \mathrm{H}-3^{\prime}, \mathrm{H}-5^{\prime}\right), 6.86(1 \mathrm{H}, \mathrm{d}$, $J=2.2 \mathrm{~Hz}, \mathrm{H}-8), 6.51(1 \mathrm{H}, \mathrm{d}, J=2.2 \mathrm{~Hz}, \mathrm{H}-6), 6.32(1 \mathrm{H}$, $s, \mathrm{H}-3), 3.14-3.53(12 \mathrm{H}, \mathrm{m}$, sugar moieties), $4.40(1 \mathrm{H}, \mathrm{d}$, $J=2 \mathrm{~Hz},-\mathrm{Rham}), 1.07\left(3 \mathrm{H}, \mathrm{d}, J=6.0 \mathrm{~Hz}, \mathrm{CH}_{3}-\mathrm{Rham}\right)$, $5.1(1 \mathrm{H}, \mathrm{d}, J=7.3 \mathrm{~Hz}, \mathrm{H}-1 \mathrm{Glu}) .{ }^{13} \mathrm{C}$ NMR data for compounds 4-6 were recorded in Table 5.

Compounds 1 and 2 gave positive Salkoweski reactions confirming their triterpenoidal nature [32]. ${ }^{1} \mathrm{H}$ - and ${ }^{13} \mathrm{C}-\mathrm{NMR}$ spectra showed that compounds 1 and 2 were pentacyclic triterpene. Compound 1 was identified as ursolic acid while compound 2 was identified as $3 \beta-O$ acetyl ursolic acid from their physical properties and their spectral data $\left({ }^{1} \mathrm{H}-\mathrm{NMR}\right.$ and $\left.{ }^{13} \mathrm{C}-\mathrm{NMR}\right)[33,34]$.

The structure of compound 3 was identified as ellagic acid from its physical properties and different spectroscopic spectra (UV and ${ }^{1} \mathrm{H}-\mathrm{NMR}$ ) [35].

\begin{tabular}{|c|c|c|c|}
\hline NO. C & $\begin{array}{l}\text { Compound } 4 \\
\mathrm{CD}_{3} \mathrm{OD}\end{array}$ & $\begin{array}{l}\text { Compound } 5 \\
\mathrm{CD}_{3} \mathrm{OD}\end{array}$ & $\begin{array}{l}\text { Compound } 6 \\
\mathrm{CD}_{3} \mathrm{OD}\end{array}$ \\
\hline 2 & 155.3 & 157.1 & 162.1 \\
\hline 3 & 137.3 & 134.2 & 103.0 \\
\hline 4 & 178.2 & 178.0 & 180.0 \\
\hline 5 & 161.0 & 161.6 & 164.3 \\
\hline 6 & 98.2 & 98.5 & 103.1 \\
\hline 7 & 164.8 & 164.6 & 160.0 \\
\hline 8 & 93.4 & 94.5 & 98.6 \\
\hline 9 & 157.4 & 156.6 & 157.0 \\
\hline 10 & 103.3 & 103.3 & 108.4 \\
\hline $1^{\prime}$ & 121.3 & 122.2 & 122.4 \\
\hline $2^{\prime}$ & 115.1 & 116.2 & 129.2 \\
\hline $3^{\prime}$ & 144.7 & 145.5 & 116.4 \\
\hline $4^{\prime}$ & 148.4 & 148.4 & 161.6 \\
\hline $5^{\prime}$ & 115.2 & 116.1 & 116.4 \\
\hline $6^{\prime}$ & 121.5 & 122.2 & 129.2 \\
\hline $\mathrm{OCH}_{3}$ & 58.2 & & \\
\hline 1" & & 101.2 & 103.3 \\
\hline $2^{\prime \prime}$ & & 73.8 & 74.9 \\
\hline 3" & & 76.8 & 77.3 \\
\hline $4^{\prime \prime}$ & & 72.5 & 72.7 \\
\hline $5^{\prime \prime}$ & & 75.8 & 76.7 \\
\hline 6" & & 67.1 & 65.9 \\
\hline $1^{\prime \prime \prime}$ & & 102.3 & 102.8 \\
\hline $2^{\prime \prime \prime}$ & & 70.8 & 70.8 \\
\hline $3^{\prime \prime \prime}$ & & 70.0 & 71.2 \\
\hline $4^{\prime \prime \prime}$ & & 71.4 & 71.4 \\
\hline $5^{\prime \prime \prime}$ & & 69.1 & 69.1 \\
\hline $6^{\prime \prime \prime}$ & & 18.1 & 18.2 \\
\hline
\end{tabular}

${ }^{1} \mathrm{H}$ and ${ }^{13} \mathrm{C}$-NMR spectra of compound 4 demonstrated a methoxy group at $\delta_{\mathrm{H}} 3.84$ and at $\delta_{\mathrm{C}} 58.2$ respectively attached at position 3 ; compound 4 was identified as quercetin 3-O - $\beta$ methyl ether [36].

The structure of compound 5 was identified as rutin from its physical properties and different spectral data (UV, ${ }^{1} \mathrm{H}-\mathrm{NMR}$ and ${ }^{13} \mathrm{C}-\mathrm{NMR}$ ) [37].

The UV $\lambda_{\max }(335 \mathrm{~nm})$ of compound 6 suggested that it possesses a flavone substituted skeleton. This was confirmed from the ${ }^{1} \mathrm{H}-\mathrm{NMR}$ spectrum. The occurrence of two doublets signals at $\delta_{\mathrm{H}} 6.51$ and $6.86(J=2.2 \mathrm{~Hz})$ indicated the presence of two meta protons at C-6 and C-8 of ring $\mathrm{A}$ respectively. In addition, 2 doublets appeared at $\delta_{\mathrm{H}} 7.03\left(2 \mathrm{H}, J=8.8 \mathrm{~Hz}\right.$, ) and at $\delta_{\mathrm{H}} 7.91$ $(2 \mathrm{H}, \mathrm{d}, J=9.1 \mathrm{~Hz})$ indicated, $\mathrm{H}-3^{\prime}, \mathrm{H}-5^{\prime}$ 'and $\mathrm{H}-2^{\prime}, \mathrm{H}-6^{\prime}$, respectively and one singlet at $\delta_{\mathrm{H}} 6.32$ for $\mathrm{H}-3$. The presence of two anomeric signals at $\delta_{\mathrm{H}} 4.40(\mathrm{~d}, J=2 \mathrm{~Hz})$ and at $5.1(\mathrm{~d}, J=7.3 \mathrm{~Hz})$ with the methyl group of rhamnose at $\delta_{\mathrm{H}} 1.07(\mathrm{~d}, J=6.0 \mathrm{~Hz})$ indicated the presence of 2 sugar units linked to $C-7$ position with $6 \rightarrow 1$ linkage. The sugar moieties were identified as glucose and rhamnose (TLC of acid hydrolysate, ${ }^{1} \mathrm{H}-\mathrm{NMR}$ and ${ }^{13} \mathrm{C}$ spectral data). Compound 6 could be identified as apigenin 7-O- $\beta$-D-glucopyranosyl ( $6 \rightarrow 1)$ - $\alpha$-L-rhamnopyranosyl (apigenin 7-O-rutinoside) [38]. Figure 1 is showing the chemical structure of the isolated compounds.

\section{Antioxidant activity \\ $D P P H$ free radical scavenging activity}

DPPH free radical scavenging effects of the extracts were tested and the results are presented in Fig. 2. Both ethanolic and methanolic extracts showed the highest activity as revealed in Fig. 2. $\mathrm{IC}_{50}$ 's of the leaves extracts were 129.2, 140.1, 164.1 and $262.3 \mu \mathrm{g} / \mathrm{mL}$ for the ethanolic, methanolic, ethyl acetate and acetone respectively. While for ascorbic acid, the $\mathrm{IC}_{50}$ was calculated to be $34.6 \mu \mathrm{g} / \mathrm{mL}$.

\section{Biological studies Antimicrobial activity}

Results displayed in Table 6 revealed that at the tested concentrations, the ethanolic extract as well its $n$-hexane fraction and the isolated compounds, ursolic acid, $3 \beta-\mathrm{O}$ acetyl ursolic acid and quercetin 3-O- methyl ether, showed variable antimicrobial activity against all the tested pathogenic strains bacteria and fungus. On the other hand, all the tested samples exhibited variable antibacterial activities with inhibition zones ranging from 18 to $28 \mathrm{~mm}$ in diameter against $P$. aeruginosa.

The isolated compound $2,3 \beta-\mathrm{O}$ acetyl ursolic acid, demonstrated the highest growth inhibitory activity against all the tested microorganisms, followed by quercetin 3-O- methyl ether and lastly, ursolic acid. 


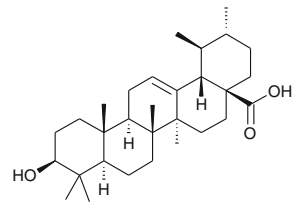

Ursolic acid

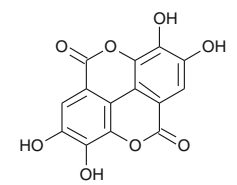

Ellagic acid

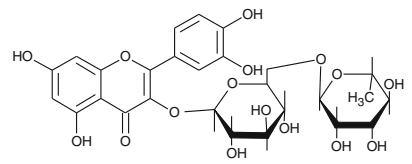

Rutin

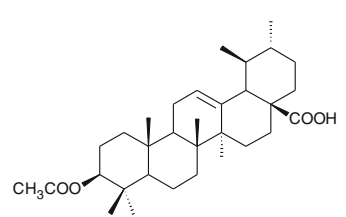

3- $\beta-O$ acetyl ursolic acid<smiles></smiles>

Quercetin 3 methyl ether

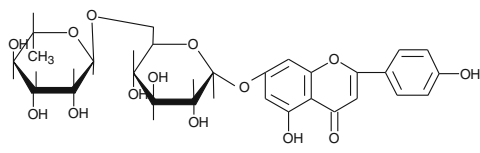

Apigenin7-O-rutinoside

Fig. 1 Compounds isolated from C. azarolus var. eu- azarolus leaves

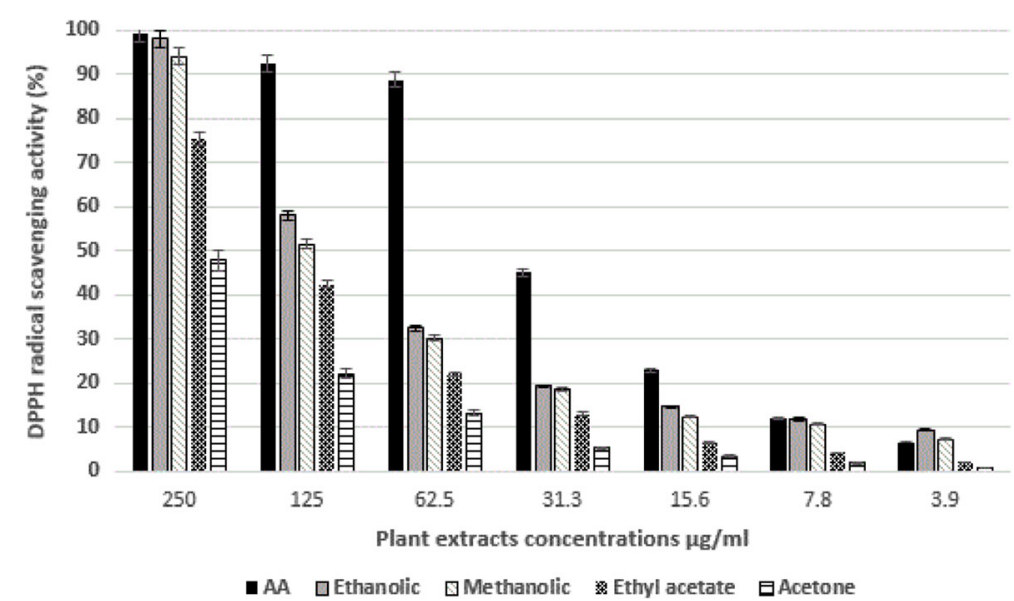

Fig. 2 2,2-Diphenyl-1-picrylhydrazyl (DPPH) radical scavenging activity of different concentrations of different extracts of C. azarolus var. eu- azarolus. Ascorbic acid (AA) was used as positive control. The data presented as mean \pm SD 
Table 6 Antimicrobial activity of the ethanolic extract, fractions and isolated compounds of C. azarolus var. eu- azarolus leaves (zone of inhibition, $\mathrm{mm}$ )

\begin{tabular}{lllll}
\hline Tested sample & S. aureus & P. aeruginosa & E. coli & C. albicans \\
\hline Ethanolic extract & $9.0 \pm 1.1$ & $22.0 \pm 2.4$ & $14.0 \pm 1.2$ & $2.0 \pm 1.2$ \\
$n$-hexane & $10.0 \pm 1.8$ & $24.0 \pm 1.6$ & $25.0 \pm 2.6$ & $22.0 \pm 3.0$ \\
Chloroform & $7.0 \pm 0.7$ & $25.0 \pm 3.3$ & $21.0 \pm 2.1$ & - \\
$n$-butanol & - & $20.0 \pm 2.1$ & $22.0 \pm 1.9$ & - \\
Ursolic acid & $23.0 \pm 2.6$ & $24.0 \pm 2.4$ & $29.0 \pm 2.3$ & $13.0 \pm 1.2$ \\
3- $\beta$-O acetyl ursolic acid & $30 \pm 3.4$ & $28.0 \pm 3.1$ & - & $15.0 \pm 0.8$ \\
Ellagic acid & - & $23.0 \pm 3.5$ & $25.0 \pm 2.8$ & - \\
Quercetin 3-O- methyl Ether & $25.0 \pm 3.1$ & $26.0 \pm 2.9$ & - & - \\
Rutin & $6.0 \pm 2.5$ & $20.0 \pm 1.8$ & - & - \\
Apigenin7-O-rutinoside & $6.0 \pm 1.9$ & $18.0 \pm 1.6$ & $22.0 \pm 3.4$ & - \\
Gentamicin & $20.0 \pm 2.7$ & $18.0 \pm 1.9$ & - & $25 \pm 2.5$ \\
Fluconazole & - & - & & \\
\hline
\end{tabular}

\section{Acute oral toxicity study}

The $\mathrm{LD}_{50}$ of the ethanolic extract of $C$. azarolus var. eu- azarolus Maire was safe up to $5000 \mathrm{mg} / \mathrm{kg}$. During the observation period, no signs of morbidity or behavioral alteration in any animals' groups were noticed.

\section{Evaluation of antihyperglycemic activity}

Oral glucose tolerance test Blood glucose levels of normal mice were significantly reduced after receiving the plant extract at different doses in a time- and dosedependent manner as shown in Fig. 3. Both doses of the leaves, as well as the isolated compound, $3 \beta-O$ acetyl ursolic acid, exhibited significant antihyperglycemic effect. The effect was significant at 30, 120 and $240 \mathrm{~min}$. Noticeable significant decrease in level of glucose was noticed at $30 \mathrm{~min}$ with the leaves extract at both doses as well as $3 \beta-\mathrm{O}$ acetyl ursolic acid at dose of $50 \mathrm{mg} / \mathrm{kg}$ $(p<0.01)$. This marked improvement in glucose tolerance was continued over the tested time.

Antihyperglycemic activity of the ethanolic extract and $3 \beta-O$ acetyl ursolic acid on blood glucose levels in diabetic mice The basal glycaemia was $241.7 \pm 1.7 \mathrm{mg} / \mathrm{dl}$ for the diabetic control mice. There was no statistical difference between the glycaemic levels of the studied groups at time $0,(p>0.05)$.

The anti-hyperglycemic activity of the ethanolic extract and the isolated compound (2) on the fasting blood sugar levels of diabetic mice is shown in Fig. 4. In diabetic mice, treatment of $C$. azarolus var. eu- azarolus leaves extract at dose of 250 and $500 \mathrm{mg} / \mathrm{kg}$ significantly lowered the basal level of blood glucose at 120 and $240 \min (p<0.01)$. A highly significant decrease of the blood glucose level was observed with $3 \beta-\mathrm{O}$ acetyl ursolic acid at the same timing intervals, $p<0.001$.

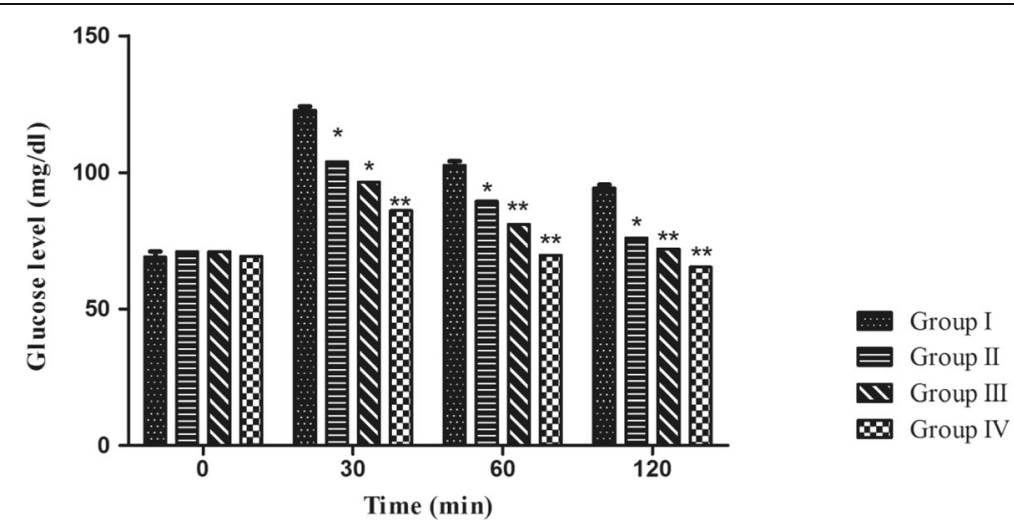

Fig. 3 Effect of ethanolic extract of C. azarolus var. eu- azarolus leaves and $3 \beta-O$ acetyl ursolic acid on glucose tolerance test, ${ }^{*} p<0.01,{ }^{* *} p<0.001$. Group I received $2 \mathrm{~g} / \mathrm{kg}$ glucose only. Groups II and III received 250 and $500 \mathrm{mg} / \mathrm{kg}$ of the plant extract respectively, and group IV received $3 \beta-O$ acetyl ursolic acid 


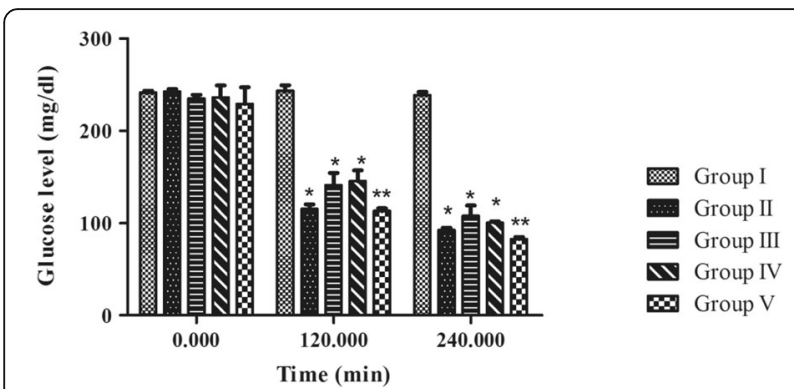

Fig. 4 Effect of ethanolic extract of C. azarolus var. eu- azarolus leaves and $3 \beta-O$ acetyl ursolic acid on glucose level in diabetic mice test, ${ }^{*} p<0.01,{ }^{* *} p<0.001$. Group I is the control, group II: positive control and received glibenclamide, group III and IV were given the plant extract at doses of 250 and $500 \mathrm{mg} / \mathrm{kg}$ respectively, and group $V$ was treated with the isolated compound

\section{Antihyperlipidemic activity}

Body weight Compared to cholesterol induced hyperlipidemic control group (group II), lovastatin treated group showed that the reference has no effect on the body weight $(p>0.05)$. On the other hand, groups received the ethanolic leaves extract showed a significant reduction in the percentage increment in body weight in day 15 and $30(p<0.01)$ as shown in Table 7.

Effect of the ethanolic extract on serum lipid profile in hyperlipidemic rats In hyperlipidemic model, groups treated with the ethanolic leaves extract and lovastatin showed significant reduction in TC, TG, LDL-C, and VLDL-C levels. In addition, serum HDL-C level was increased as compared to the control group (Table 8). Treated Groups with lovastatin and the leaves ethanolic extract demonstrated remarkable decrease in the "Atherogenic Index" and LDL-C: HDL-C risk ratios.

In-vitro effect of the ethanolic extract and $3 \beta-O$ acetyl ursolic acid on pancreatic lipase and HMGCoA reductase activities $C$. azarolus var. eu- azarolus ethanolic extract at concentrations of $50-500 \mu \mathrm{g} / \mathrm{mL}$ reduced the activity of pancreatic lipase in-vitro.
Significant reduction was noticed at concentrations of $200-500 \mu \mathrm{g} / \mathrm{mL}$ of $40.6-98.5 \%$ respectively with $\mathrm{IC}_{50}$ $252.3 \mu \mathrm{g} / \mathrm{mL}$ compared to orlistat ( $\left.\mathrm{IC}_{50} 0.59 \mu \mathrm{g} / \mathrm{mL}\right)$. Moreover, 3- $\beta-\mathrm{O}$ acetyl ursolic acid at concentrations between 80 and $200 \mu \mathrm{g} / \mathrm{mL}$ significantly reduced the pancreatic lipase activity with $42.4-99.6 \%$ and the $\mathrm{IC}_{50}$ was $93.6 \mu \mathrm{g} / \mathrm{mL}$. On the other hand, the plant extract showed moderate inhibition of HMGCoA reductase activity at concentrations between 350 and $500 \mu \mathrm{g} / \mathrm{mL}$ of $42.6-60 \%$ with $\mathrm{IC}_{50} 394.1 \mu \mathrm{g} / \mathrm{mL}$ compared to pravastatin that has $\mathrm{IC}_{50}$ of $0.71 \mu \mathrm{g} / \mathrm{mL} .3-\beta-\mathrm{O}$ acetyl ursolic acid didn't show any significant inhibition of HMGCoA at the tested concentration.

\section{Discussion}

Diabetes Mellitus and other hyperglycemic disorders are complicated conditions associated with high prevalence of infection, dyslipidemia, hypertension and renal failure. The aim of this study was to find a standard plant extract that has the potential to control hyperglycemia with its associated complications, and to isolate and identify the active components that are responsible for those activities.

Results of total phenolic and flavonoid contents revealed that ethanol was the best solvent to extract both flavonoid and phenolic acids. Therefore, ethanol had been selected for further investigations. RP- HPLC analysis of the phenolics demonstrated high contents of rutin, salicylic and ellagic acids in the plant. Six compounds belonging to triterpenes and phenolic were isolated from chloroform and $n$-butanol fractions for the first time from C. azarolus var. eu- azarolus Maire. Ursolic acid is a triterpenoidal compound that finds in medicinal herbs, other plants and foods [39]. Ursolic acid showed anti-inflammatory, hepatoprotective, antihyperlipidemic, anticancer, inhibition of lipid peroxidation and antimicrobial activities [39-43]. Most of the available scientific papers are concerned about the activity of ursolic acid with no data regarding the antihyperglycemic and antihyperlipdimic of its acetate

Table 7 Percentage increment in the experimental groups' body weight for 30 days treatment period

\begin{tabular}{|c|c|c|c|c|}
\hline Group & Treatment (p.o.) & Day 0 & Day 15 & Day 30 \\
\hline । & $1 \%$ w/v sodium CMC & $211.3 \pm 3.6$ & $\begin{array}{l}236.1 \pm 4.3 \\
(+11.9 \pm 0.5)\end{array}$ & $\begin{array}{l}253.2 \pm 3.4 \\
(+20.2 \pm 0.4)\end{array}$ \\
\hline$\|$ & Cholesterol & $209.3 \pm 2.8$ & $\begin{array}{l}250.4 \pm 3.6 \\
(+19.8 \pm 0.5)^{\#}\end{array}$ & $\begin{array}{l}273.1 \pm 4.6 \\
(+30.5 \pm 0.3)^{\#}\end{array}$ \\
\hline III & Cholesterol + lovastatin & $212.4 \pm 3.6$ & $\begin{array}{l}252.1 \pm 2.4 \\
(+18.7 \pm 0.3)\end{array}$ & $\begin{array}{l}272.1 \pm 3.4 \\
(+28.1 \pm 0.6)\end{array}$ \\
\hline IV & Cholesterol + plant extract $250 \mathrm{mg} / \mathrm{kg}$ & $211.8 \pm 4.2$ & $\begin{array}{l}244.4 \pm 5.1 \\
(+15.4 \pm 0.3)^{*}\end{array}$ & $\begin{array}{l}250.1 \pm 3.5 \\
(+18.1 \pm 0.6)^{* *}\end{array}$ \\
\hline V & Cholesterol + plant extract 500 mg/kg & $210.6 \pm 5.3$ & $\begin{array}{l}241.1 \pm 4.3 \\
(+14.5 \pm 0.2)^{*}\end{array}$ & $\begin{array}{l}247.8 \pm 5.3 \\
(+17.7 \pm 0.8)\rangle^{* *}\end{array}$ \\
\hline
\end{tabular}

$\# p<0.01$ vs group I; ${ }^{*, * *} p<0.05$ and 0.01 vs cholesterol induced hyperlipidemic control group respectively 
Table 8 Effect of C. azarolus var. eu- azarolus leaves extract on serum lipid profile, Atherogenic Index and LDL-C/HDL-C ratio in hyperlipidemic rats in hyperlipidemic rats (values are represented as Mean \pm SEM)

\begin{tabular}{|c|c|c|c|c|c|c|c|}
\hline Group & Total cholesterol (mg/dl) & Triglyceride (mg/dl) & $\mathrm{HDL}-\mathrm{C}(\mathrm{mg} / \mathrm{dl})$ & $\mathrm{LDL}-\mathrm{C}(\mathrm{mg} / \mathrm{dl})$ & VLDL-C (mg/dl) & Atherogenic index & $\mathrm{LDL}-\mathrm{C} / \mathrm{HDL}-\mathrm{C}$ \\
\hline I & $61.7 \pm 2.4$ & $60.5 \pm 5.6$ & $36.3 \pm 1.1$ & $22.0 \pm 0.7$ & $12.4 \pm 0.5$ & $1.7 \pm 0.3$ & $0.6 \pm 0.02$ \\
\hline ॥ & $84.5 \pm 2.5 \#$ & $127.5 \pm 2.5 \#$ & $26.0 \pm 1.1 \#$ & $39.1 \pm 1.3 \#$ & $16.9 \pm 0.6 \#$ & $3.25 \pm 0.7$ & $1.5 \pm 0.2$ \\
\hline III & $\begin{array}{l}61.5 \pm 0.5^{* *} \\
(-27.2 \%)\end{array}$ & $\begin{array}{l}58.0 \pm 2.1^{* *} \\
(-54.5 \%)\end{array}$ & $\begin{array}{l}33.5 \pm 0.5^{* *} \\
(+28.8 \%)\end{array}$ & $\begin{array}{l}24.3 \pm 1.1^{* *} \\
(-37.9 \%)\end{array}$ & $\begin{array}{l}12.3 \pm 0.1^{*} \\
(-27.2 \%)\end{array}$ & $1.8 \pm 0.2$ & $0.7 \pm 0.05$ \\
\hline IV & $\begin{array}{l}78.3 \pm 3.4 \\
(-7.3 \%)\end{array}$ & $\begin{array}{l}61.3 \pm 6.9^{* *} \\
(-51.9 \%)\end{array}$ & $\begin{array}{l}30.2 \pm 1.4^{*} \\
(+16.2 \%)\end{array}$ & $\begin{array}{l}26.5 \pm 0.6^{* *} \\
(-32.2 \%)\end{array}$ & $\begin{array}{l}15.7 \pm 0.7 \\
(-7.1 \%)\end{array}$ & $2.6 \pm 0.6$ & $0.9 \pm 0.04$ \\
\hline V & $\begin{array}{l}61.7 \pm 1.8^{* *} \\
(-27.0 \%)\end{array}$ & $\begin{array}{l}49.0 \pm 2.5^{* *} \\
(-61.6 \%)\end{array}$ & $\begin{array}{l}32.5 \pm 0.6^{* *} \\
(+25.0 \%)\end{array}$ & $\begin{array}{l}25.2 \pm 0.7^{* *} \\
(-35.6 \%)\end{array}$ & $\begin{array}{l}12.9 \pm 0.4^{*} \\
(-23.7 \%)\end{array}$ & $1.9 \pm 0.3$ & $0.8 \pm 0.05$ \\
\hline
\end{tabular}

Group I: Control group received the vehicle, groups II-V were hyperlipidemic and received daily cholesterol (25 mg/kg/day) in oil at 10:00 am. Group II received cholesterol, group III received lovastatin, groups IV and V were given the plant extract at doses of 250 and 500 respectively. \# $p<0.01$ vs group I, * and ** $p<0.05$ and 0.01 vs cholesterol induced hyperlipidemic control group respectively

derivative. The most common approach to reversibly derivatize hydroxy groups is binding it with acyl groups. Thus, acetate prodrugs are characterized by favorable pharmacokinetic properties and rates of activation [44, 45]. Therefore, $3-\beta-O$ acetyl ursolic acid is assumed to have better pharmacokinetics features than ursolic acid itself. In-vitro DPPH assay was used to evaluate the free radical-scavenging effect of the leaves extracts of different solvents. The ethanolic extract showed the highest DPPH radical scavenger potential. This effect could be attributed to the ursolic acid and the phenolic compounds that were isolated from the ethanolic leaves extract. Ursolic acid, a pentacyclic triterpene, was reported to be a strong oxygen species (ROS) scavenger. Similarly, phenolic compounds including flavonoids particularly, quercetin 3-O $-\beta$ methyl ether, rutin and apigenin 7-O- $\beta$-D-glucopyranosyl $(6 \rightarrow 1)-\alpha$-Lrhamnopyranosyl and phenolic acids (ellagic and salicylic acids) have been described to have high antioxidant effects [46-49]. Hyperglycemia worsens the development of infections and vice versa [50]. Blood glucose of more than $200 \mathrm{mg} / \mathrm{dL}$ has been strongly associated with reduced neutrophil activity [51]. Diabetic patients are at higher risk of infections from various microorganisms viz. S. aureus, E. coli, $P$. aeruginosa and C. albicans $[52,53]$. The ethanolic leaves extract as well, its fractions and the isolated compounds exhibited noticeable antimicrobial activities against a wide range of microorganisms. This effect could support the immune system to fight against invading microorganism. Antipseudomonal activity of the chloroform extract could be ascribed to its isolated compounds namely, ursolic, $3 \beta-O$ acetyl ursolic and ellagic acids through individual action or in a synergistic way. Other antimicrobial activities of chloroform fraction could be basically related to the triterpenes content only since ellagic acid appeared to be inactive on the other microorganisms. On the other hand, $n$ - butanol fraction showed inhibition activity against both $P$. aeruginosa and E. coli. These activities are essentially linked to the phenolic constituents namely, quercetin 3-O-methyl ether, rutin and apigenin 7O- $\beta$-D-glucopyranosyl $(6 \rightarrow 1)$ - $\alpha$-L-rhamnopyranosyl. For the biological studies, doses were selected depending on the $\mathrm{LD}_{50}$ value $(<1 / 10)$. Blood glucose levels of normal and diabetic mice received either ethanolic extract or $3 \beta-\mathrm{O}$ acetyl ursolic acid, were significantly decreased in a time- and dose-dependent manner. It has been previously reported that ursolic acid improves hepatic insulin resistance by stimulating the expression of peroxisome proliferator-activated receptors $\alpha$ (PPAR $\alpha)$ [54]. Moreover, ursolic acid is reported to have high $\alpha$-glucosidase inhibitory activity [55]. Those effects explained the antihyperglycemic activity of ursolic acid on fasting state and glucose tolerance test. Furthermore, ellagic acid is reported to possess antidiabetic action through inhibition of glycogen phosphorylase b enzyme [56]. Polyphenolic compounds, including quercetin $3-\mathrm{O}-\beta$ methyl ether, rutin and apigenin 7-O- rutinoside are reported to have antihyperglycemic effect $[57,58]$. Such combination of triterpenes and phenolic compounds could have synergistic antihyperglycemic actions. On the other hand, administration of the ethanolic leaves extract markedly decreased the percentile increment in body weight. Furthermore, the leaves extract significantly reduced the serum TC, TG, LDL-C, VLDL-C and increased HDL-C levels. Pancreatic lipase and HMGCoA reductase were used to explore the possible mechanisms for the antihyperlipidemic action. Both ethanolic extract and $3 \beta-\mathrm{O}$ acetyl ursolic acid reduced in-vitro activity of pancreatic lipase. In contrary, the extract showed moderate inhibition of HMGCoA reductase, while $3-\beta-O$ acetyl ursolic acid was unable to inhibit the enzyme activity at the tested doses. Based on that, antihyperlipidemic effect of the ethanolic extract can't be solely contributed to HMGCoA inhibition. Thus, another mechanism could be suggested. Ursolic acid is reported to enhance the binding of PPAR- $\alpha$ to the response element in PPAR- $\alpha$-responsive genes and modifies the lipid metabolism genes expression [59]. Thereby regulating the transcription of PPAR- $\alpha$ genes involved in lipid metabolism. 
Additionally, it reduces cellular cholesterol and triglyceride levels in hepatocytes, possibly by increasing the uptake and oxidation of fatty acid and by inhibiting their synthesis [59]. Interestingly, the enzymatic assay confirmed the inhibitory activity of the ethanoic extract and 3- $\beta-\mathrm{O}$ acetyl ursolic acid on pancreatic lipase. Hence, the antihyperlipidemic effect of the ethanolic extract and attenuation of body weight gain might be due to its inhibitory action on pancreatic lipase.

\section{Conclusion}

The current study demonstrates the efficiency of the leaves extract of C. azarolus var. eu-azarolus Maire in controlling hyperglycemia with its associated complications such as infection and dyslipidemia. This multiple pharmacological profile might be due to the synergistic effect of its bioactive constituents including triterpenes, particularly ursolic acid and its acetyl derivative, and the phenolic compounds particularly, quercetin 3-O $-\beta$ methyl ether, rutin and apigenin 7 -O-rutinoside. This study is unique in the sense that it is the first to evaluate the antihyperglycemic and antihyperlipidemic potentialities of $3 \beta-\mathrm{O}$ acetyl ursolic acid.

\section{Additional file}

Additional file 1: RP-HPLC chromatograms of the phenolic contents at $\lambda=280$ and $330 \mathrm{~nm}$. (DOCX $566 \mathrm{~kb}$ )

\section{Abbreviations}

DPPH: 2, 2-diphenyl-1-picrylhydrazyl; HDL-C: High density lipoprotein cholesterol; LDL-C: Low density lipoprotein cholesterol; PPAR: Peroxisome proliferator-activated receptors; TC: Total cholesterol; TG: Triglycerides; VLDLC: Very low density lipoprotein cholesterol

\section{Acknowledgement}

The authors are indebted to Prof. S. A. Khan, Dean of the Dubai Pharmacy College, in accomplishing this work. We would like also to thank Mrs. Salam Estwani, Sara Safa, Heba Basmaji, Manal Khalid, Asmaa Rami, Fatima Elzahra Kamal and Hala Azam for their assistance in biochemical analysis work.

\section{Funding}

This research received no specific grant from any funding.

\section{Availability of data and materials}

The datasets supporting the conclusions of this article are included within the article.

\section{Authors' contributions}

EAG and NGS designed the experimental work, wrote the manuscript. Specifically, research idea and in-vitro, in-vivo experiments, statistical data and results analysis done by Dr. EAG. Dr. NGS was responsible for the leaves extraction, measurement of total phenolic and flavonoid contents, fractionation, isolation of the active constituents, interpretation of RP- HPLC and NMR results. Both authors approved the final article.

\section{Competing interests}

The authors declare that they have no competing interests.

\section{Consent for publication}

Not applicable.

\section{Ethics approval}

All animal investigations were performed according to the ethical standards for the proper care and use of laboratory animals and upon approval of the Ethical Research Committee at Dubai Pharmacy College, Dubai UAE.

\section{Publisher's Note}

Springer Nature remains neutral with regard to jurisdictional claims in published maps and institutional affiliations.

\section{Author details}

${ }^{1}$ Department of Basic Medical Sciences, College of Medicine, University of Sharjah, Sharjah, United Arab Emirates. ${ }^{2}$ Department of Pharmacology and Toxicology, Dubai Pharmacy College, Dubai, United Arab Emirates.

${ }^{3}$ Department of Pharmacognosy, Faculty of Pharmacy, Cairo University, Giza, Egypt.

Received: 20 December 2016 Accepted: 6 April 2017

Published online: 18 April 2017

\section{References}

1. Jafar $\mathrm{N}$, Edriss $H$, Nugent $\mathrm{K}$. The effect of short-term hyperglycemia on the innate immune system. Am J Med Sci. 2016;351:201-11.

2. Goldstein JL, Schrott HG, Hazzard WR, Bierman EL, Motulsky AG Hyperlipidemia in coronary heart disease. II. Genetic analysis of lipid levels in 176 families and delineation of a new inherited disorder, combined hyperlipidemia. J Clin Invest. 1973;52:1544-68.

3. World Health Organisation. WHO traditional medicine strategy: 2014-2023. http://www.who.int/medicines/publications/traditional/trm_strategy14_23/ en. Accessed 2 May 2016.

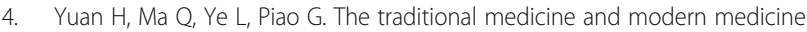
from natural products. Molecules. 2016;21:559.

5. Christensen Kl. Revision of Crataegus sect. Crataegus and Nothosect. Crataeguineae (Rosaceae: Maloideae) in the old world. Ame Soc Plant Taxonom. 1992;35:199.

6. Bahri-Sahloul R, Ben Fredj R, Boughalleb N, et al. Phenolic composition and antioxidant and antimicrobial activities of extracts obtained from Crataegus azarolus L. var. aronia (Willd.) Batt. Ovaries Calli. J Botany. 2014;2014:11.

7. Khalil R, Abuharfeil N, Shabsoug B. The effect of Crataegus aronica aqueous extract in rabbits fed with high cholesterol diet. Eur J Scientific Res. 2008:22:352-60.

8. Bahorun T, Trotin F, Pommery J, Vasseur J, Pinkas M. Antioxidant activities of Crataegus monogyna extracts. Planta Med. 1994;60:323-8.

9. Kao ES, Wang CJ, Lin WL, Yin YF, Wang CP, Tseng TH. Anti-inflammatory potential of flavonoid contents from dried fruit of Crataegus pinnatifida in vitro and in vivo. J Agric Food Chem. 2005:53:430-6.

10. Kumar D, Arya V, Bhat ZA, Khan NA, Prasad DN. The genus Crataegus: chemical and pharmacological perspectives. Rev Bras. 2012:22:1187-200.

11. Benmalek Y, Yahia OA, Belkebir A, Fardeau ML. Anti-microbial and antioxidant activities of Illicium verum, Crataegus oxyacantha ssp monogyna and Allium cepa red and white varieties. Bioengineered. 2013;4:244-8.

12. Wang J, Xiong X, Feng B. Effect of crataegus usage in cardiovascular disease prevention: an evidence-based approach. Evid Based Complement Alternat Med. 2013;2013:149363.

13. Tassell MC, Kingston R, Gilroy D, Lehane M, Furey A. Hawthorn (Crataegus spp.) in the treatment of cardiovascular disease. Pharmacogn Rev. 2010;4:32-41.

14. Chowdhury SS, Islam MN, Jung HA, Choi JS. In vitro antidiabetic potential of the fruits of Crataegus pinnatifida. Res Pharm Sci. 2014;9:11-22.

15. Soko-Letowska A, Oszmianski J, Wojdyo A. Antioxidant activity of the phenolic compounds of hawthorn, pine and skullcap. Food Chem. 2007;103:853-9.

16. Liu P, Kallio H, Lu D, Zhou C, Yang B. Quantitative analysis of phenolic compounds in Chinese hawthorn (Crataegus spp.) fruits by high performance liquid chromatography-electrospray ionisation mass spectrometry. Food Chem. 2011;127:1370-7.

17. Baram AH, Banaz J. Determination of Flavonoids in the leaves of hawthorn (Crataegus Azarolus) of Iraqi Kurdistan region by HPLC analysis. Int J Biosci Biochem Bioinforma. 2013;3:67-70.

18. Duke JA. Handbook of Phytochemical constituents of GRAS herbs and other economic plants (and database) Boca Raton. Florida: CRC Press, Inc; 1992. 
19. Oktay M, Gulcin I, Kufrevioglu Ol. Determination of in vitro antioxidant activity of fennel (Foeniculum vulgare) seed extracts. LWT Food Sci Technol. 2003;36:263-71.

20. Dewanto V, Wu X, Adom KK, Liu RH. Thermal processing enhances the nutritional value of tomatoes by increasing total antioxidant activity. J Agric Food Chem. 2002;50:3010-4.

21. Goupy P, Hugues M, Boivin P, Amiot MJ. Antioxidant composition and activity of barley (Hordeum vulgare) and malt extracts and of isolated phenolic compounds. J Sci Food Agric. 1999;79:1625-34.

22. Mattila P, Astola J, Kumpulainen J. Determination of Flavonoids in plant material by HPLC with diode-Array and electro-Array detections. J Agric Food Chem. 2000;48:5834-41.

23. Shehab NG, Abu-Gharbieh E, Bayoumi FA. Impact of phenolic composition on hepatoprotective and antioxidant effects of four desert medicinal plants. BMC Complement Altern Med. 2015;15:401.

24. Cheng Z, Moore J, Yu L. High-throughput relative DPPH radical scavenging capacity assay. J Agric Food Chem. 2006;54:7429-36.

25. Lorian V. Antibiotics in laboratory medicine. 5th ed. Philadelphia: Lippincott Williams and Wilkins; 2005.

26. National Research Council (US) Committee for the Update of the Guide for the Care and Use of Laboratory Animals. Guide for the Care and Use of Laboratory Animals. 2011.

27. Lorke D. A new approach to practical acute toxicity testing. Arch Toxicol. 1983:54:275-87.

28. Syiem D, Syngai G, Khup PZ, Khongwir BS, Kharbuli B, Kayang H. Hypoglycemic effects of Potentilla fulgens $L$ in normal and alloxan-induced diabetic mice. J Ethnopharmacol. 2002;83:55-61.

29. Arichi H, Kimura Y, Okuda H, Baba K, Kozawa M, Arichi S. Effects of stilbene components of the roots of Polygonum cuspidatum Sieb. Et Zucc. On lipid metabolism. Chem Pharm Bull (Tokyo). 1982;30:1766-70.

30. Kim YS, Lee YM, Kim H, et al. Anti-obesity effect of Morus bombycis root extract: anti-lipase activity and lipolytic effect. J Ethnopharmacol. 2010;130:621-4.

31. Xie W, Wang W, Su H, Xing D, Cai G, Du L. Hypolipidemic mechanisms of Ananas comosus L. leaves in mice: different from fibrates but similar to statins. J Pharmacol Sci. 2007:103:267-74.

32. Finar IL. Organic chemistry, The Fundamental Principles. 4th ed, Vol 1. New York: Wiley; 1963.

33. Do Nascimento GP, Lemos LT, Bizerra MA, et al. Antibacterial and antioxidant activities of Ursolic acid and derivatives. Molecules. 2014;19:1317-27.

34. Martins D, Carrion LL, Ramos DF, et al. Triterpenes and the antimycobacterial activity of Duroia macrophylla Huber (Rubiaceae). Biomed Res Int. 2013;2013:605831.

35. Yan XH, Guo YW. Two new ellagic acid glycosides from leaves of Diplopanax stachyanthus. J Asian Nat Prod Res. 2004;6:271-6.

36. Krenn L, Miron A, Pemp E, Petr U, Kopp B. Flavonoids from Achillea nobilis L. Z Naturforsch C. 2003;58:11-6.

37. Biruk S, Kaleab A, Raghavendra Y. Radical scavenging activities of the leaf extracts and a flavonoid glycoside isolated from Cineraria abyssinica Sch. Bip. Exa. Rich. J App Pharmac Sci. 2012;2:44-9.

38. Moon BH, Lee SC, et al. Complete assignments of the $1 \mathrm{H}$ and $13 \mathrm{C}$ NMR data of Flavone derivatives. Bull Kor Chem Soc. 2005;26:603-8.

39. Liu J. Pharmacology of oleanolic acid and ursolic acid. J Ethnopharmacol. 1995:49:57-68

40. Ovesna Z, Kozics K, Slamenova D. Protective effects of ursolic acid and oleanolic acid in leukemic cells. Mutat Res. 2006;600:131-7.

41. Ramachandran S, Prasad NR. Effect of ursolic acid, a triterpenoid antioxidant, on ultraviolet-B radiation-induced cytotoxicity, lipid peroxidation and DNA damage in human lymphocytes. Chem Biol Interact. 2008;176:99-107.

42. Huang CY, Lin CY, Tsai CW, Yin MC. Inhibition of cell proliferation, invasion and migration by ursolic acid in human lung cancer cell lines. Toxicol in Vitro. 2011;25:1274-80

43. Somova LO, Nadar A, Rammanan P, Shode FO. Cardiovascular, antihyperlipidemic and antioxidant effects of oleanolic and ursolic acids in experimental hypertension. Phytomedicine. 2003;10:115-21.

44. Jana S, Mandlekar S, Marathe P. Prodrug design to improve pharmacokinetic and drug delivery properties: challenges to the discovery scientists. Curr Med Chem. 2010;17:3874-908.

45. Prodrug TB. Objectives and design A2 - Taylor, John B. In: Triggle DJ, editor. Comprehensive medicinal chemistry II. Oxford: Elsevier; 2007. p. 1009-41.
46. Li ZG. Synergistic effect of antioxidant system and osmolyte in hydrogen sulfide and salicylic acid crosstalk-induced heat tolerance in maize (Zea mays L.) seedlings. Plant Signal Behav. 2015;10:e105-1278.

47. Usta C, Ozdemir S, Schiariti M, Schiariti MF, Puddu PE. The pharmacological use of ellagic acid-rich pomegranate fruit. Int J Food Sci Nutr. 2013;64:907-13.

48. Lee $\mathrm{YH}, \mathrm{Kim} \mathrm{HJ}, \mathrm{Yoo} \mathrm{H}$, et al. Synthesis of (2-amino) ethyl derivatives of quercetin 3-O-methyl ether and their antioxidant and neuroprotective effects. Bioorg Med Chem. 2015.

49. Metodiewa D, Kochman AF, Karolczak S. Evidence for antiradical and antioxidant properties of four biologically active $\mathrm{N}, \mathrm{N}$-diethylaminoethyl ethers of flavanone oximes: a comparison with natural polyphenolic flavonoid (rutin) action. Biochem Mol Biol Int. 1997:1067-75.

50. Koh GC, Peacock SJ, van der PT, Wiersinga WJ. The impact of diabetes on the pathogenesis of sepsis. Eur J Clin Microbiol Infect Dis. 2012;31:379-88.

51. Pettersson US, Christoffersson G, Massena S, et al. Increased recruitment but impaired function of leukocytes during inflammation in mouse models of type 1 and type 2 diabetes. PLoS One. 2011;6:e22480.

52. Casqueiro J, Casqueiro J, Alves C. Infections in patients with diabetes mellitus: a review of pathogenesis. Indian J Endocrinol Metab. 2012;16(Suppl 1):S27-36.

53. Knapp S. Diabetes and infection: is there a link? A mini-review. Gerontology. 2013:59:99-104

54. Wang L, Wang GL, Liu JH, Li D, Zhu DZ, Wu LN. Effects of ursolic acid in ameliorating insulin resistance in liver of KKAy mice via peroxisome proliferator-activated receptors alpha and gamma. Zhong Xi Yi Jie He Xue Bao. 2012:10:793-9.

55. He K, Song S, Zou Z, et al. The Hypoglycemic and synergistic effect of Loganin, Morroniside, and Ursolic acid isolated from the fruits of Cornus officinalis. Phytother Res. 2016:283-91.

56. Kyriakis E, Stravodimos GA, Kantsadi AL, Chatzileontiadou DS, Skamnaki VT, Leonidas DD. Natural flavonoids as antidiabetic agents. The binding of gallic and ellagic acids to glycogen phosphorylase b. FEBS Lett. 2015:1787-94.

57. Habtemariam S, Lentini $\mathrm{G}$. The therapeutic potential of rutin for diabetes: an update. Mini Rev Med Chem. 2015;15:524-8.

58. Jadhav R, Puchchakayala G. Hypoglycemic and antidiabetic activity of flavonoids: boswellic acid, ellagic acid, quercetin, rutin on streptozotocinnicotinamide induced type 2 diabetic rats. Int J Pharm Pharm Sci. 2012;4:251-6.

59. Jia Y, Bhuiyan MJ, Jun HJ, et al. Ursolic acid is a PPAR-alpha agonist that regulates hepatic lipid metabolism. Bioorg Med Chem Lett. 2011;21:5876-80.

\section{Submit your next manuscript to BioMed Central and we will help you at every step:}

- We accept pre-submission inquiries

- Our selector tool helps you to find the most relevant journal

- We provide round the clock customer support

- Convenient online submission

- Thorough peer review

- Inclusion in PubMed and all major indexing services

- Maximum visibility for your research

Submit your manuscript at www.biomedcentral.com/submit 